\title{
Implementasi Pendidikan Nilai Karakter di Sekolah Dasar Melalui Budaya Sekolah
}

\author{
Aryuna Kusuma Tria Dewi ${ }^{1}$, I Nyoman Sudana Degeng ${ }^{2}$, Syamsul Hadi $^{3}$ \\ ${ }^{1}$ Pendidikan Dasar-Universitas Negeri Malang \\ ${ }^{2}$ Teknologi Pendidikan-Universitas Negeri Malang \\ ${ }^{3}$ Teknik Mesin-Universitas Negeri Malang
}

\section{INFO ARTIKEL}

\section{Riwayat Artikel:}

Diterima: 30-11-2018

Disetujui: 20-02-2019

\section{Kata kunci:}

implementation; character building; school culture; implementasi; pendidikan karakter; budaya sekolah

\author{
Alamat Korespondensi: \\ Aryuna Kusuma Tria Dewi \\ Pendidikan Dasar \\ Universitas Negeri Malang \\ Jalan Semarang 5 Malang \\ E-mail:aryunatria.at@gmail.com
}

\begin{abstract}
This research was aimed to knowing the implementation of character education through school culture. with a focus on religious character, discipline character and independent character. This study used a qualitative approach with the design of the study of multi case (multycase studies). The data collection technique of this research were the observation, interviews, and documentation. The results of the study showed that the implementation of character education through school culture focused on religious character, discipline, and independence. Each character is obtained through routine activities, spontaneous activities, and exemplary.
\end{abstract}

ABSTRAK

\begin{abstract}
Abstrak: Penelitian ini bertujuan untuk mengetahui implementasi pendidikan karakter melalui budaya sekolah dengan fokus karakter religius, karakter disiplin, dan karakter mandiri. Penelitian ini menggunakan pendekatan kualitatif dengan rancangan studi multi kasus (multycase studies). Teknik observasi, wawancara, dan studi dokumentasi digunakan dalam pengambilan data pada penelitian ini. Hasil penelitian menunjukkan bahwa pelaksanaan pendidikan karakter melalui budaya sekolah difokuskan pada karakter agama, disiplin, dan kemandirian. Setiap karakter diperoleh melalui kegiatan rutin, kegiatan spontan, dan keteladanan.
\end{abstract}

Pendidikan karakter merupakan usaha untuk mengembangkan karakter sehingga mampu mencapai nilai-nilai karakter yang diinginkan oleh bangsa.Pendidikan karakter melalui komponen pengetahuan, kesadaran, kemauan, dan tindakan untuk melaksanakan nilai-nilai karakter yang ditanamkan kepada warga sekolah (Jusita, 2006). Hal tersebut sejalan dengan pendapat (Duncan, 2007). yang menjelaskan bahwa pendidikan karakter saat ini bergerak ke arah yang benar Maksudnya pendidikan karakter dapat menghasilkan perkembangan keterampilan, pengetahuan, dan kebiasaan moral yang bermanfaat. Memiliki nilai dan pendidikan karakter yang baik dapat menumbuhkan sikap positif dari siswa (Freeks, 2015). (Almerico, 2014) menjelaskan bahwa pendidikan karakter dapat digambarkan sebagai bagian dari kurikulum yang dikembangkan secara khusus untuk mengajarkan siswa supaya berkualitas dan memiliki karakter yang baik.

Pendidikan karakter diberlakukan pada setiap jenjang pendidikan, mulai dari pendidikan dasar sampai pendidikan tinggi. Pendidikan karakter lebih ditekankan pada pendidikan dasar karena jika karakter tidak terbentuk sejak dini maka akan susah untuk merubah karakter seseorang. Implementasi pendidikan karakter dengan tepat dapat membangun masyarakat yang unggul termasuk siswa. Siswa yang unggul tidak hanya ditumbuhkan kecerdasan menalar saja, tetapi juga harus ditumbuhkan kecerdasan segi moral. Hal tersebut sejalan dengan pendapat (Rahim, Raisul, \& Abdoludin, 2016) yang menjelaskan bahwa pentingnya keseimbangan antara aspek kognitif dan afektif dalam sistem pendidikan terus menerus dilakukan untuk meningkatkan kualitas pendidikan

Keberhasilan pendidikan karakter di sekolah dipengaruhi oleh budaya sekolah yang positif. (Wiyani, 2013) menjelaskan bahwa budaya sekolah merupakan salah satu faktor yang berpengaruh terhadap perkembangan siswa. Budaya sekolah disesuaikan dengan nilai setiap sekolah. Dari pembiasaan disekolah kemudian akan muncul tindakan yang jika dilakukan secara konsisten akan menjadi sebuah budaya dan akan menjadi identitas dari sekolah itu sendiri. Menurut (Marini, 2017) menjelaskan bahwa nilai karakter dapat diintegrasikan tidak hanya di ruang kelas, tetapi dapat melalui budaya sekolah. Sejalan dengan (Thresia, 2015) yang menjelaskan bahwa budaya dan pendidikan karakter nasional dipandang sebagai solusi cerdas untuk menghasilkan siswa yang memiliki moralitas, kepribadian, dan menjunjung tinggi nilai Indonesia secara menyeluruh 
Penelitian ini mengambil fokus pada tiga nilai karakter, yaitu religius, disiplin, dan mandiri. Religius adalah sikap dan perilaku yang patuh dalam melaksanakan ajaran agama yang dianutnya, toleran terhadap pelaksanaan ibadah agama lain, dan hidup rukun dengan pemeluk agama lain. Menurut (Thontowi, 2005) nilai religius merupakan suatu bentuk hubungan manusia dengan penciptanya melalui ajaran agama yang sudah terinternalisasi dalam diri seseorang dan tercermin dalam sikap dan perilakunya sehari-hari.

Menurut (Covaleskie, 2006) karakter baik yang dimiliki seseorang tidak dapat berkembang tanpa adanya disiplin. (Simba, Agak, \& Kabuka, 2016) menyimpulkan bahwa dalam konteks sekolah, siswa yang disiplin adalah siswa yang memiliki perilaku dan tindakan yang sesuai dengan peraturan sekolah yang telah ditentukan. Dari beberapa pengertian dari disiplin, dapat disimpulkan bahwa disiplin adalah tindakan dan perilaku tertib dan patuh sesuai dengan peraturan. (Shangaraeva \& Yarkhamova, 2016) menjelaskan bahwa kemandirian didefinisikan dalam pedagogik sebagai salah satu karakteristik kepribadian. Dari beberapa pengertian tersebut dapat disimpulkan bahwa nilai mandiri merupakan salah satu karakteristik kepribadian yang tidak mudah bergantung pada orang lain dan mampu memenuhi kebutuhan sendiri dengan upaya yang dimiliki. (Sunarty \& Dirawan, 2015) menjelaskan bahwa banyak faktor yang memengaruhi kemandirian anak yang dibagi ke dalam faktor internal dan faktor eksternal.

Berdasarkan hasil wawancara yang dilakukan peneliti di sekolah pertama yaitu SD Al-Muqoddasah dengan kepala sekolah, ditemukan beberapa hal yang menarik. Seluruh siswa di sekolah ini wajib tinggal di asrama karena dapat dikatakan bahwa sekolah ini merupakan sebuah pondok, namun SD Al-Muqoddasah ini masih bernaung dibawah Dinas Pendidikan. Sekolah yang berdiri tanggal 5 Mei 1995 ini memiliki 270 siswa. Hal lain yang menarik yang lainnya, siswa di sekolah ini mayoritas berasal dari luar daerah Ponorogo. Karena pihak sekolah tidak ingin sekolah lain yang berada di daerah pondok tidak mendapatkan siswa jika banyak siswa yang bersekolah di SD Al-Muqoddasah. Menurut kepala SD Al-Muqoddasah yaitu M, sekolah ini sudah menerapkan pendidikan karakter sejak sekolah berdiri.

Berdasarkan nilai-nilai karakter yang ditetapkan Pemerintah terdapat beberapa nilai karakter yang lebih menonjol, yaitu nilai religius, disiplin, dan kemandirian karena sekolah ini berbasis asrama, jadi seluruh siswa dituntut untuk dapat hidup mandiri selama berada di pondok. Sebagai siswa pondok, selain mandiri juga harus memiliki sikap disiplin karena sekolah tersebut memiliki peraturan yang harus dipatuhi oleh seluruh siswa. Contohnya setiap hari seluruh siswa harus bangun pukul 03.30 pagi kemudian mandi dan persiapan sholat subuh. Seluruh siswa mengikuti kegiatan hafalan Al-Qur'an setelah sholat subuh hingga pukul 07.00, selanjutnya siswa makan pagi dan mempersiapkan diri untuk sekolah. Baru pukul 7.30 siswa masuk ke dalam kelas dan menerima pelajaran sekolah, seperti sekolah yang lain pada umumnya. Selain itu, budaya sekolah yang nampak ketika siswa akan memulai pelajaran yaitu salah satu siswa secara mandiri membuka pintu kelas masing-masing dan melaksanakan apel pagi secara bersama-sama tanpa ada arahan dari guru.

Sekolah selanjutnya yang dituju oleh peneliti untuk dilakukan penelitian tentang pelaksanaan nilai karakter yaitu SD Darussalam. Peneliti tertarik dengan sekolah ini karena sekolah Darussalam merupakan sekolah baru yang berjalan sekitar lima tahun, tetapi sudah memiliki 222 siswa dan terkenal dengan pendidikan karakter yang baik menurut masyarakat sekitar. Berbeda dengan SD Al-Muqoddasah yang mewajibkan seluruh siswa untuk asrama, SD Darussalam ini layaknya, seperti sekolah biasa. Darussalam tidak hanya mempunyai SD, tetapi juga memiliki Pendidikan Anak Usia Dini. Menurut hasil wawancara dengan kepala SD Darussalam, siswa yang diterima di sekolah ini merupakan alumni dari PAUD Darussalam dan hanya beberapa yang diterima dari luar sekolah tersebut. Menurut beliau, pendidikan karakter sudah dikenalkan semenjak siswa berada di PAUD.

Seluruh nilai karakter dari peraturan telah diterapkan dalam sekolah ini. Namun, ada beberapa nilai yang lebih menonjol yaitu religius, disiplin, dan kemandirian. Pada sekolah ini dibiasakan untuk baris sebelum masuk kelas. Peraturan-peraturan yang telah ditetapkan harus dipatuhi oleh seluruh siswa dan apabila dilanggar akan mendapatkan sanksi. SD Darussalam juga memiliki kegiatan ekstrakurikuler beragam yang dimaksudkan untuk menunjang potensi siswa sejak dini, seperti bahasa Inggris, bela diri, baca Al-Qur'an, futsal, mewarnai, menggambar. Peneliti memfokuskan penelitian pada tiga nilai karakter, yaitu religius, disiplin, dan mandiri. Oleh karena itu, penelitan ini berfokus pada "Implementasi Pendidikan Karakter di Sekolah Dasar Kecamatan Mlarak Ponorogo (Studi Multi Kasus di SD Al-Muqoddasah dan SD Darussalam)”.

\section{METODE}

Penelitian ini menggunakan pendekatan kualitatif dengan rancangan studi multi kasus (multycase studies). Metode pengambilan data yang digunakan dalam penelitian ini, yaitu (1) wawancara, (2) observasi, dan (3) dokumentasi. Teknik observasi yang digunakan oleh peneliti yaitu teknik observasi partisipatif karena peneliti akan ikut langsung meneliti di SD Al-Muqoddasah dan SD Darussalam. Selain observasi, pengumpulan data dilakukan dengan wawancara yang dilakukan kepada kepala sekolah, guru kelas dan beberapa siswa terkait dengan implementasi pendidikan karakter melalui budaya sekolah. Selanjutnya, studi dokumentasi digunakan dengan tujuan untuk dapat mendukung hasil temuan wawancara dan observasi. Analisis data dilakukan dengan cara mereduksi data, menyajikan data, dan menarik kesimpulan (Miles dan Huberman, 1992). 
Tabel 1. Kisi-Kisi Pedoman Wawancara untuk Guru

\begin{tabular}{cl}
\hline No. & Indikator \\
\hline 1. & Pemahaman guru tentang pendidikan karakter \\
2. & Pelaksanaan pendidikan karakter religius, disiplin, dan mandiri \\
3. & Kegiatan rutin dalam budaya sekolah \\
4. & Kegiatan spontan dalam budaya sekolah \\
5. & Keteladanan dalam budaya sekolah \\
6. & Hukuman yang diberikan ketika siswa melanggar \\
\hline
\end{tabular}

Langkah selanjutnya setelah reduksi data dengan merangkum data yang telah dikumpulkan yakni penyajian data. Penyajian data pada penelitian kualitatif bersifat naratif. Data yang disajikan terkait tentang implementasi pendidikan karakter dengan fokus nilai religius, disiplin, dan mandiri melalui pembiasaan budaya sekolah di SD Al-Muqoddasah dan SDIT Darussalam. Selanjutnya, tahap terakhir yaitu menarik kesimpulan dari data tentang implementasi pendidikan karakter dengan fokus nilai religius, disiplin, dan mandiri melalui pembiasaan budaya sekolah di SD Al-Muqoddasah dan SDIT Darussalam.

Temuan hasil penelitian berupa simpulan tersebut kemudian dicek keabsahannya. Pengecekan keabsahan data dilakukan dari awal penelitian hingga semua data terkumpul. Data yang terkumpul merupakan hasil dari observasi, wawancara, dan dokumentasi tentang implementasi karakter khususnya karakter religius, disiplin, dan mandiri melalui budaya sekolah di SD AlMuqoddasah dan SDIT Darussalam. Pengecekan keabsahan data dalam penelitian kualitatif dapat dilakukan dengan cara uji kredibilitas, uji transferabilitas, uji dependabilitas, dan uji konfirmabilitas.

\section{HASIL}

\section{Implementasi Pendidikan Karakter melalui Budaya Sekolah di Sekolah Dasar}

Hasil yang diperoleh dalam penelitian tentang hasil analisis dengan fokus (1) implementasi karakter religius di sekolah dasar, (2) implementasi karakter disiplin di sekolah dasar, dan (3) implementasi karakter mandiri di sekolah dasar.

\section{Implementasi Pendidikan Karakter Religius di SD Al-Muqodassah}

Implementasi nilai karakter religius melalui budaya sekolah di SD Al-Muqoddasah dapat dilihat dari kegiatan rutin, kegiatan spontan, dan keteladanan. Temuan penelitian yang diperoleh berdasarkan sub fokus kegiatan rutin, meliputi (1) kegiatan sholat lima waktu secara berjamaah yang dilaksanakan di masijid Al-Muqoddasah dan diikuti oleh seluruh warga sekolah; (2) tahfidz Qur'an (menghafal ayat suci Al-Qur'an) merupakan kegiatan yang diutamakan di SD Al-Muqoddasah dan dilaksanakan dua kali dalam sehari secara berkelompok, (3) muhadhoroh yang merupakan acara pidato bertemakan Islami dan dilaksanakan setiap sabtu setelah sholat maghrib; (4) sholat rawatib (sholat sunnah sebelum dan sesudah sholat wajib) yang dilaksanakan secara individu oleh siswa setiap sholat wajib lima waktu; (5) sholat Jumat bagi siswa laki-laki.

Temuan penelitian yang diperoleh berdasarkan sub fokus kegiatan spontan, meliputi (a) puasa sunnah Senin dan Kamis yang dilaksanakan oleh sebagian besar siswa tanpa ada paksaan dari pihak manapun; (b) sholat sunnah dhuha yang dilaksanakan sebagian besar siswa setelah mengaji pagi hari atau pada saat istirahat sekolah. Temuan penelitian yang diperoleh berdasarkan sub fokus keteladanan, meliputi (a) menutup aurat yang dilaksanakan oleh seluruh warga sekolah dan bagi guru selalu memberikan keteladanan untuk menutup aurat secara syari; (b) selalu memanfaatkan waktu luang untuk membaca Al-Qur'an.

\section{Implementasi Pendidikan Karakter Religius di SD Darussalam}

Pelaksanaan karakter religius di SDIT Darussalam melalui budaya sekolah sudah berjalan dengan baik dan dibuktikan dengan beberapa kegiatan. Pelaksanaan nilai karakter disiplin melalui budaya sekolah di SD Al-Muqoddasah ini dilakukan melalui kegiatan rutin, kegiatan spontan, dan keteladanan. Kegiatan rutin dapat dilihat meliputi; (1) Sholat dhuha setiap pukul 09.00 WIB; (2) tahfidz Qur'an yang dilaksanakan setelah sholat sholat dhuha; (3) sholat dhuhur dan ashar berjamaah; (4) muhadhoroh setiap hari sabtu; (5) sholat Jumat bagi siswa laki-laki. Kegiatan spontan, meliputi (1) mengaji sebelum sholat; (2) mengumandangkan adzan. Keteladanan dalam nilai karakter religius yang dapat dicontoh dari guru, meliputi (1) sholat tepat waktu; (2) hafal juz 30; (3) menutup aurat.

\section{Analisis Lintas Kasus}

Temuan lintas kasus pelaksanaan karakter religius pada kasus 1 (SD Al-Muqoddasah) dan kasus 2 (SDIT Darussalam) dapat dilihat pada tabel 2 .

Berdasarkan analisis lintas kasus pada tabel 2 di atas dapat disimpulkan bahwa pelaksanaan karakter religius melalui budaya sekolah diperoleh tiga kategori yaitu kegiatan rutin, kegiatan spontan, dan keteladanan. Kegiatan rutin dalam karakter religius melalui budaya sekolah dapat dilihat dari beberapa kegiatan, meliputi (1) sholat wajib berjamaah; (2) tahfidz Qur'an; (3) muhadhoroh; (4) sholat Jumat bagi siswa laki-laki. Kegiatan spontan dalam karakter religius melalui budaya, meliputi (1) puasa sunah hari Senin dan Kamis; (2) sholat dhuha; (3) mengaji sebelum sholat; (4) mengumandangkan adzan. Keteladanan yang dapat dicontoh dari kepala sekolah, guru, dan tenaga pendidik yaitu menutup aurat dan sholat tepat waktu. 
Tabel 2. Temuan Lintas Kasus Pelaksanaan Karakter Religius

\begin{tabular}{|c|c|c|c|}
\hline No. & Sub Fokus & $\begin{array}{c}\text { Kasus 1 } \\
\text { SD Al-Muqoddasah }\end{array}$ & $\begin{array}{c}\text { Kasus } 2 \\
\text { SDIT Darussalam }\end{array}$ \\
\hline 1. & Kegiata Rutin & $\begin{array}{l}\text { Sholat } 5 \text { waktu berjamaah } \\
\text { Tahfidz Quran dilaksanakan dua kali dalam sehari } \\
\text { Muhadhoroh setiap hari Sabtu } \\
\text { Sholat Rawatib yang dilaksanakan sebelum atau sesudah } \\
\text { sholat wajib } \\
\text { Sholat Jumat bagi siswa laki-laki }\end{array}$ & $\begin{array}{l}\text { Sholat dhuhur dan ashar berjamaah } \\
\text { Tahfidz Qur'an setiap hari setelah sholat } \\
\text { dhuha } \\
\text { Sholat dhuha } \\
\text { Muhadhoroh setiap hari Sabtu } \\
\text { Sholat Jumat bagi siswa laki-laki }\end{array}$ \\
\hline 2. & $\begin{array}{l}\text { Kegiatan } \\
\text { Spontan }\end{array}$ & $\begin{array}{l}\text { Puasa sunah hari Senin dan Kamis } \\
\text { Sholat Dhuha }\end{array}$ & $\begin{array}{l}\text { Mengaji sebelum sholat } \\
\text { Mengumandangkan adzan }\end{array}$ \\
\hline 3. & Keteladanan & $\begin{array}{l}\text { Menutup aurat } \\
\text { Membaca Al-Quran ketika waktu luang }\end{array}$ & $\begin{array}{l}\text { Sholat tepat waktu } \\
\text { Menutup aurat }\end{array}$ \\
\hline
\end{tabular}

\section{Implementasi Pendidikan Karakter Disiplin di SD Al-Muqoddasah}

Nilai karakter disiplin merupakan salah satu karakter penting yang harus dimiliki oleh seluruh siswa termasuk siswa di SD Al-Muqoddasah. Karakter disiplin di SD Al-Muqoddasah ini tercantum dalam tata tertib yang harus ditaati oleh siswa selama 24 jam. Pelaksanaan nilai karakter disiplin melalui budaya sekolah di SD Al-Muqoddasah ini dilakukan melalui kegiatan rutin, kegiatan spontan, dan keteladanan. Temuan penelitian yang diperoleh berdasarkan sub fokus kegiatan rutin, meliputi (1) setiap hari seluruh siswa harus bangun tepat waktu yaitu pukul 03.30 WIB dan membersihkan diri untuk mempersiapkan sholat subuh berjamaah; (2) seluruh siswa datang ke masjid tepat waktu untuk melaksanakan sholat berjamaah; (3) ketika di masjid siswa dilarang ramai sendiri atau berbicara dengan siswa lain, para siswa harus beribadah dengan khusyu' dan mengikuti dzikir dengan baik; (4) selalu membiasakan untuk mengantri dalam mengambil makan; (5) seluruh siswa dilarang berhubungan dengan lawan jenis tanpa ada alasan yang jelas, kecuali siswa kelas 1 dan $2 ;(6)$ siswa diajarkan berhemat sejak dini dengan diberikan uang saku sebesar Rp.5000,00 dalam satu hari; (7) seluruh siswa diperbolehkan pulang ke rumah hanya satu kali dalam satu tahun; (8) siswa dalam sekolah ini hanya mendapatkan jadwal kunjungan satu kali dalam satu bulan dan tidak diperbolehkan menghubungi keluarga kecuali pihak keluarga yang menghubungi pihak sekolah terlebih dahulu. Temuan penelitian yang diperoleh berdasarkan sub fokus kegiatan spontan, yaitu ketika siswa melanggar peraturan akan mendapatkan hukuman saat itu juga. Hukuman yang diterima oleh siswa tergantung oleh pelanggaran yang dilakukan oleh siswa. Temuan penelitian yang diperoleh berdasarkan sub fokus keteladanan, meliputi (1) mentaati tata tertib; (2) guru datang ke masjid tepat waktu untuk sholat berjamaah; (3) berpakaian rapi.

\section{Implementasi Pendidikan Karakter Disiplin di SD Darussalam}

Pelaksanaan karakter disiplin di SDIT Darussalam melalui budaya sekolah sudah berjalan dengan baik dan dibuktikan dengan beberapa kegiatan. Pelaksanaan nilai karakter disiplin melalui budaya sekolah di SD Al-Muqoddasah ini dilakukan melalui kegiatan rutin, kegiatan spontan, dan keteladanan. Kegiatan rutin, meliputi (1) budaya mengantri ketika makan siang dan mencuci piring; (2) ketika makan harus dalam keadaan duduk; (3) sholat dengan tepat waktu; (4) tata tertib berdoa yang dibacakan sebelum berdoa; (5) kegiatan ekstrakurikuler bela diri dan pramuka. Kegiatan spontan yang dilakukan siswa untuk mewujudkan karakter disiplin melalui budaya sekolah yaitu siswa yang melanggar peraturan mendapat hukuman. Keteladanan dalam nilai karakter religius yang dapat dicontoh dari guru yaitu datang tepat waktu.

\section{Analisis Lintas Kasus}

Temuan lintas kasus pelaksanaan karakter disiplin pada kasus 1 (SD Al-Muqoddasah) dan kasus 2 (SDIT Darussalam) dapat dilihat pada tabel 3 .

\section{Implementasi Pendidikan Karakter Mandiri di SD Al-Muqoddasah}

Peneliti melakukan penelitian di SD Al-Muqoddasah karena sekolah ini merupakan sebuah pondok yang mewajibkan seluruh siswa agar dapat hidup mandiri tanpa menyusahkan orang lain. Pelaksanaan pendidikan nilai karakter mandiri melalui budaya sekolah di SD Al-Muqoddasah terdiri atas kegiatan rutin, kegiatan spontan, dan kegiatan keteladanan sebagai berikut.

SD Al-Muqoddasah sudah menerapkan pendidikan karakter mandiri dengan sangat baik karena siswa dituntut untuk mandiri selama 24 jam. Pelaksanaan pendidikan karakter mandiri melalui budaya sekolah terlihat dari kegiatan rutin, kegiatan spontan, dan keteladanan. Kegiatan rutin dapat dilihat melalui (1) merapikan perlengkapan tidur, (2) mandi dan persiapan sekolah, (3) peraturan makan, (4) apel pagi, dan (5) merapikan kamar. Sementara itu, kegiatan spontan yang dapat dilihat dari siswa, seperti membuka pintu kelas dan membersihkan ruang kantor guru. Untuk keteladanan yang dapat dicontoh dari tenaga pendidik sekolah dalam kegiatan mandiri yaitu membersihkan kamar dan selalu menjaga kebersihan. 


\section{Implementasi Pendidikan Karakter di SD Darussalam}

Pelaksanaan karakter mandiri di SDIT Darussalam melalui budaya sekolah sudah berjalan dengan baik dan dibuktikan dengan beberapa kegiatan. Pelaksanaan nilai karakter disiplin melalui budaya sekolah di SD Al-Muqoddasah ini dilakukan melalui kegiatan rutin, kegiatan spontan, dan keteladanan. Kegiatan rutin dapat dilihat dari (1) mengambil makan dan mencuci piring secara mandiri; (2) meletakkan sepatu pada rak sepatu di depan kelas masing-masing; (3) melipat mukena dan meletakkan di rak mukena. Kegiatan spontan dalam karakter mandiri yaitu salah satu siswa mengambil makanan ringan untuk teman sekelasnya. Keteladanan dalam nilai karakter religius yang dapat dicontoh dari guru yaitu merapikan meja kerja, baik meja di kelas maupun di ruang guru.

\section{Analisis Lintas Kasus}

Temuan lintas kasus pelaksanaan karakter mandiri pada kasus 1 (SD Al-Muqoddasah) dan kasus 2 (SDIT Darussalam) dapat dilihat dalam tabel 4.

Tabel 3. Temuan Lintas Kasus Pelaksanaan Karakter Disiplin

\begin{tabular}{|c|c|c|c|}
\hline No. & Sub Fokus & $\begin{array}{c}\text { Kasus 1 } \\
\text { SD Al-Muqoddasah }\end{array}$ & $\begin{array}{c}\text { Kasus } 2 \\
\text { SDIT Darussalam }\end{array}$ \\
\hline \multirow[t]{6}{*}{1.} & Kegiata Rutin & $\begin{array}{l}\text { Setiap hari seluruh siswa harus bangun tepat waktu yaitu pukul } \\
03.30 \text { WIB }\end{array}$ & $\begin{array}{l}\text { Budaya mengantri ketika } \\
\text { makan siang dan mencuci } \\
\text { piring }\end{array}$ \\
\hline & & $\begin{array}{l}\text { Seluruh siswa datang ke masjid tepat waktu untuk melaksanakan } \\
\text { sholat berjamaah }\end{array}$ & $\begin{array}{l}\text { Ketika makan harus dalam } \\
\text { keadaan duduk }\end{array}$ \\
\hline & & $\begin{array}{l}\text { Ketika di masjid siswa dilarang ramai sendiri atau berbicara dengan } \\
\text { siswa lain, para siswa harus beribadah dengan khusyu' dan } \\
\text { mengikuti dzikir dengan baik }\end{array}$ & $\begin{array}{l}\text { Sholat dengan tepat waktu } \\
\text { Tata tertib berdoa yang } \\
\text { dibacakan sebelum berdoa }\end{array}$ \\
\hline & & $\begin{array}{l}\text { Selalu membiasakan untuk mengantri dalam mengambil makan } \\
\text { Seluruh siswa dilarang berhubungan dengan lawan jenis tanpa ada } \\
\text { alasan yang jelas kecuali kelas } 1 \text { dan kelas } 2\end{array}$ & $\begin{array}{l}\text { Kegiatan ekstrakurikuler } \\
\text { bela diri dan pramuka }\end{array}$ \\
\hline & & $\begin{array}{l}\text { Siswa diajarkan berhemat sejak dini dengan diberikan uang saku } \\
\text { sebesar Rp. } 5000,00 \text { dalam satu hari } \\
\text { Seluruh siswa diperbolehkan pulang ke rumah hanya satu kali } \\
\text { dalam satu tahun }\end{array}$ & \\
\hline & & $\begin{array}{l}\text { Siswa dalam sekolah ini hanya mendapatkan jadwal kunjungan } \\
\text { satu kali dalam satu bulan }\end{array}$ & \\
\hline 2. & Kegiatan Spontan & Ketika siswa melanggar peraturan akan mendapatkan hukuman & $\begin{array}{l}\text { Siswa yang melanggar } \\
\text { peraturan mendapat }\end{array}$ \\
\hline \multirow[t]{2}{*}{3.} & Keteladanan & $\begin{array}{l}\text { Mentaati tata tertib } \\
\text { Guru datang ke masjid tepat waktu }\end{array}$ & hukuman \\
\hline & & Berpakaian rapi & Datang tepat waktu \\
\hline
\end{tabular}

Tabel 4. Temuan Lintas Kasus Pelaksanaan Karakter Mandiri

\begin{tabular}{|c|c|c|c|}
\hline No. & Sub Fokus & $\begin{array}{c}\text { Kasus 1 } \\
\text { SD Al-Muqoddasah }\end{array}$ & $\begin{array}{c}\text { Kasus } 2 \\
\text { SDIT Darussalam }\end{array}$ \\
\hline 1. & Kegiata Rutin & $\begin{array}{l}\text { Merapikan perlengkapan tidur } \\
\text { Mandi dan persiapan sekolah } \\
\text { Peraturan makan } \\
\text { Apel pagi } \\
\text { Membersihkan kamar }\end{array}$ & $\begin{array}{l}\text { Mengambil makan dan mencuci piring secara } \\
\text { mandiri } \\
\text { Meletakkan sepatu pada rak sepatu di depan kelas } \\
\text { masing-masing } \\
\text { Melipat mukena dan meletakkan di rak mukena }\end{array}$ \\
\hline 2. & $\begin{array}{l}\text { Kegiatan } \\
\text { Spontan }\end{array}$ & $\begin{array}{l}\text { Membuka pintu kelas dan membersihkan } \\
\text { ruang kantor guru }\end{array}$ & $\begin{array}{l}\text { Salah satu siswa mengambil makanan ringan } \\
\text { untuk teman sekelasnya }\end{array}$ \\
\hline 3. & Keteladanan & $\begin{array}{l}\text { Membersihkan kamar dan selalu menjaga } \\
\text { kebersihan. }\end{array}$ & $\begin{array}{l}\text { Merapikan meja kerja baik meja di kelas maupun } \\
\text { di ruang guru }\end{array}$ \\
\hline
\end{tabular}


Berdasarkan analisis lintas kasus pada tabel 4 di atas dapat disimpulkan bahwa pelaksanaan karakter mandiri melalui budaya sekolah diperoleh tiga kategori, yaitu kegiatan rutin, kegiatan spontan, dan keteladanan.

Kegiatan rutin dalam karakter mandiri melalui budaya sekolah dapat dilihat dari beberapa kegiatan, meliputi (1) mengambil makan dan mencuci piring secara mandiri dan (2) melipat mukena bagi siswa perempuan. Kegiatan spontan dalam karakter mandiri melalui budaya yaitu siswa secara suka rela membantu teman sekelasnya, seperti membuka pintu kelas atau mengambil makanan ringan. Keteladanan yang dapat dicontoh dari kepala sekolah, guru, dan tenaga pendidik yaitu selalu menjaga kebersihan.

\section{PEMBAHASAN}

Dalam implementasi pendidikan karakter berbasis budaya sekolah di sekolah dasar (Multi Kasus di SD Al-Muqoddasah dan SD Darussalam Kecamatan Mlarak Kabupaten Ponorogo), meliputi karakter religius, disiplin, dan mandiri.

\section{Implementasi Pendidikan Karakter Religius}

Pendidikan karakter religius di sekolah dasar berbasis budaya sekolah dilaksanakan melalui kegiatan rutin, kegiatan spontan, dan keteladanan. Hal tersebut sesuai dengan Kemendiknas (2013) yang menyatakan bahwa kegiatan rutin, kegiatan spontan, dan keteladanan merupakan penginternalisasian nilai-nilai karakter melalui budaya sekolah (Kementerian Pendidikan dan Kebudayaan, 2013). Hal tersebut sesuai dengan Gunawan (2012) yang menyatakan bahwa pendidikan karakter melalui budaya sekolah dapat dilaksanakan melalui kegiatan rutin, kegiatan sepontan, dan keteladanan.

\section{Kegiatan Rutin}

Kegiatan rutin merupakan kegiatan yang dilaksanakan siswa secara berulang dan tetap setiap saat (Samani, 2012). Sejalan dengan pendapat (Sulistiyo, 2014)yang menjelaskan bahwa kegiatan rutin merupakan kegiatan yang dilakukan terusmenerus oleh siswa ajeg. Penjabaran dari kegiatan rutin dari karakter religius di sekolah dasar, meliputi (1) sholat wajib berjamaah; (2) tahfidz Qur'an; (3) muhadhoroh; (4) sholat Jumat bagi siswa laki-laki.

\section{Kegiatan Spontan}

Kegiatan spontan dapat diartikan dengan kegiatan yang dilakukan siswa secara spontan atau langsung. Menurut Gunawan (2012) menjelaskan bahwa kegiatan spontan adalah kegiatan yang dilakukan siswa secara spontan pada saat itu juga. Berdasarkan penelitian yang dilaksanakan di sekolah dasar ditemukan beberapa kegiatan spontan, meliputi (1) puasa sunah hari Senin dan Kamis; (2) sholat dhuha; (3) mengaji sebelum sholat; (4) mengumandangkan adzan.

\section{Keteladanan}

(Narwanti, 2011) menjelaskan bahwa keteladanan merupakan tindakan yang dicontohkan oleh guru yang berupa perilaku dan sikap yang baik supaya diikuti oleh siswa, seperti disiplin, kerapian, kebersihan, kesopanan, perhatian, kasih sayang, dan sebagainya. Berdasarkan penelitian di sekolah dasar disimpulkan bahwa keteladanan yang dapat dicontoh dalam karakter religius yaitu menutup aurat dan sholat tepat waktu.

Berdasarkan temuan penelitian tersebut dapat disimpulkan bahwa sekolah dasar sudah melakukan pendidikan karakter religius dengan baik. Seperti yang telah dijelaskan oleh (Kementerian Pendidikan Nasional, 2010) bahwa indikator sekolah yang haru dicapai siswa dalam karakter religius yaitu (1) merayakan hari-hari besar keagamaan, (2) memiliki fasilitas yang dapat digunakan untuk beribadah, dan (3) memberikan kesempatan kepada semua peserta didik untuk melaksanakan ibadah.

\section{Implementasi Pendidikan Karakter Disiplin}

Husdarta (2010) menjelaskan bahwa disiplin dapat diartikan sebagai kontrol penguasaan diri terhadap impuls yang tidak diinginkan atau proses mengarahkan impuls pada suatu cita-cita atau tujuan tertentu untuk mencapai dampak yang lebih besar. Berdasarkan hasil penelitian, pendidikan karakter disiplin di sekolah dasar berbasis budaya sekolah dilaksanakan melalui kegiatan rutin, kegiatan spontan, dan keteladanan yaitu sebagai berikut.

\section{Kegiatan Rutin}

Kegiatan rutin merupakan kegiatan yang dilakukan siswa secara terus menerus dan konsisten setiap saat (Muslich, 2011). Sejalan dengan pendapat Sulistyowati (2012) yang menjelaskan bahwa kegiatan rutin merupakan kegiatan yang terus-menerus dilakukan siswa secara konsisten. Penjabaran kegiatan rutin dari karakter disiplin di sekolah dasar, meliputi (1) budaya mengantri ketika makan dan mencuci piring; (2) sholat tepat waktu. 


\section{Kegiatan Spontan}

Kegiatan spontan merupakan kegiatan yang dilakukan siswa secara langsung. Menurut Gunawan (2012) menjelaskan bahwa kegiatan spontan adalah kegiatan yang dilakukan siswa secara spontan pada saat itu juga. Berdasarkan penelitian yang dilaksanakan di sekolah dasar ditemukan beberapa kegiatan spontan dalam karakter disiplin yaitu mendapatkan hukuman bagi siswa yang melanggar peraturan. Hukuman bersifat mendidik dan disesuaikan dengan kesalahan yang diperbuat.

\section{Keteladanan}

Keteladanan merupakan perilaku atau sikap guru dan tenaga kependidikan dalam memberikan contoh melalui tindakantindakan yang baik, sehingga diharapkan menjadi panutan bagi siswa (Gunawan, 2012). Berdasarkan penelitian di sekolah dasar disimpulkan bahwa keteladanan yang dapat dicontoh dalam karakter disiplin yaitu datang tepat waktu ketika sholat maupun ke sekolah. Menurut (Wantah, 2015) yang menjelaskan bahwa saat menerapkan disiplin pada siswa terdapat lima unsur penting yang dapat digunakan sekolah dalam menerapkan sikap disiplin siswa sebagai berikut.

\section{Peraturan}

Peraturan dalam sekolah biasanya berupa tata tertib yang harus ditaati oleh seluruh warga sekolah yaitu siswa, guru, dan karyawan sekolah. Dalam penelitian yang dilaskanakan di sekolah dasar, sekolah sudah membuat peraturan atau tata tertib yang harus dipatuhi oleh seluruh warga sekolah selama berada di sekolah.

\section{Kebiasaan}

Dalam penelitian ditemukan bahwa terdapat kebiasaan-kebiasaan yang dilakukan oleh warga sekolah, seperti sholat berjamaah tepat waktu, mengaji, mengantri saat makan dan mencuci piring.

\section{Hukuman}

Hukuman yang diberikan harus dapat memotivasi siswa. Siswa di sekolah dasar yang menjadi tempat penelitian juga mendapatkan hukuman ketika mereka melakukan kesalahan. Contohnya pada saat upacara ada salah satu siswa yang tidak membawa topi, maka siswa tersebut berdiri menghadap ke peserta upacara. Selain itu ketika siswa terlambat untuk menunaikan sholat berjamaah, siswa akan mendapatkan hukuman untuk mengucapkan "istighfar" selama 5 menit setelah sholat.

\section{Penghargaan}

Pemberian penghargaan diharapkan dapat membantu semangat siswa untuk lebih berprestasi. Ketika peneliti melaksanakan penelitian, peneliti menemukan penghargaan yang diterima siswa yaitu ketika siswa menjawab pertanyaan dengan benar maka siswa mendapatkan tepuk tangan dari teman-teman satu kelas.

\section{Implementasi Pendidikan Karakter Mandiri}

Nilai mandiri merupakan salah satu karakteristik kepribadian yang tidak mudah bergantung pada orang lain dan mampu memenuhi kebutuhan sendiri dengan upaya yang dimiliki. Berdasarkan hasil penelitian, ditemukan bahwa pendidikan karakter mandiri melalui budaya sekolah dilaksanakan melalui kegiatan rutin, spontan, dan keteladanan.

\section{Kegiatan Rutin}

Kegiatan rutin merupakan kegiatan yang dilaksanakan siswa secara terus-menerus dan konsisten setiap saat (Samani, 2012). Sejalan dengan Muslich (2011) yang menyebutkan bahwa kegiatan rutin merupakan kegiatan yang dilakukan siswa secara terus menerus dan konsisten setiap saat. Berdasarkan penelitian yang telah dilaksanakan ditemukan bahwa penjabaran kegiatan rutin yaitu mengambil makan dan mencuci piring secara mandiri dan melipat mukena bagi siswa perempuan.

\section{Kegiatan Spontan}

Kegiatan spontan merupakan kegiatan yang dilakukan siswa secara langsung. Menurut Gunawan (2012) menjelaskan bahwa kegiatan spontan adalah kegiatan yang dilakukan siswa secara spontan pada saat itu juga. Berdasarkan penelitian yang dilaksanakan di sekolah dasar ditemukan beberapa kegiatan spontan dalam karakter mandiri yaitu siswa secara suka rela membantu teman sekelasnya, seperti membuka pintu kelas atau mengambil makanan ringan.

\section{Keteladanan}

Narwanti (2011) menjelaskan bahwa keteladanan merupakan tindakan yang dicontohkan oleh guru yang berupa perilaku dan sikap yang baik supaya diikuti oleh siswa, seperti disiplin, kerapian, kebersihan, kesopanan, perhatian, kasih sayang, dan sebagainya. Berdasarkan penelitian di sekolah dasar disimpulkan bahwa keteladanan yang dapat dicontoh dalam karakter mandiri yaitu selalu menjaga kebersihan dan kebersihan. 
Kemendiknas (2010) mengungkapkan bahwa nilai mandiri dalam pendidikan karakter memiliki indikator yang harus dicapai oleh siswa. Indikator sekolah yang harus dicapai yaitu menciptakan situasi sekolah yang membangun kemandirian siswa. Sedangkan indikator kelas yang harus dicapai yaitu menciptakan suasana kelas yang memberikan kesempatan kepada siswa untuk bekerja mandiri. Berdasarkan penelitian yang ditemukan oleh peneliti tentang implementasi pendidikan karakter mandiri di sekolah dasar bahwa sekolah sudah melaksanakan dengan baik. Hal tersebut dibuktikan dengan sebagian besar siswa telah mandiri ketika berada di lingkungan sekolah.

\section{SIMPULAN}

Berdasarkan hasil penelitian yang telah dilaksanakan, peneliti menyimpulkan bahwa implementasi nilai karakter religius, disiplin, dan mandiri melalui budaya sekolah sudah dilaksanakan dengan cukup baik. Secara rinci dapat dijelaskan sebagai berikut.

Pertama, implementasi nilai karakter religius terlihat pada beberapa kegiatan yang sudah menjadi budaya sekolah. Kegiatan tersebut meliputi: (1) sholat wajib berjamaah; (2) tahfidz Qur'an; (3) muhadhoroh; (4) sholat Jumat bagi siswa laki-laki; (5) puasa sunah hari Senin dan Kamis; (6) sholat dhuha; (7) mengaji sebelum sholat; (8) mengumandangkan adzan.

Kedua, implementasi nilai karakter disiplin terlihat pada beberapa kegiatan yang sudah menjadi budaya sekolah. Kegiatan tersebut, meliputi (1) budaya mengantri ketika makan dan mencuci piring; (2) sholat tepat waktu; (3) mendapatkan hukuman bagi siswa yang melanggar peraturan.

Ketiga, implementasi nilai karakter mandiri terlihat pada beberapa kegiatan yang sudah menjadi budaya sekolah. Kegiatan tersebut, meliputi (1) mengambil makan dan mencuci piring secara mandiri; (2) melipat mukena bagi siswa perempuan; (3) siswa secara suka rela membantu teman sekelasnya seperti membuka pintu kelas atau mengambil makanan ringan; (4) keteladanan yang dapat dicontoh yaitu selalu menjaga kebersihan dan kebersihan.

Berdasarkan simpulan penelitian, disarankan agar diadakan (1) pelatihan tentang pendidikan karakter melalui budaya sekolah pada Kurikulum 2013 untuk meningkatkan kemampuan guru dalam mengimplementasikan pendidikan karakter khususnya dalam budaya sekolah di sekolah dasar dimonitoring oleh kepala sekolah hendaknya tetap dilaksanakan; (2) evaluasi yang dilaksanakan oleh guru pada setiap harinya lebih dioptimalkan lagi agar implementasi pendidikan karakter dapat terlaksana lebih baik dan sesuai dengan tujuan; (3) sekolah dapat lebih mengoptimalkan peran orangtua dengan menjadwalkan pertemuan secara rutin agar terbentuk hubungan jalinan hubungan yang baik antara orangtua dan sekolah untuk mendukung pelaksanaan pendidikan karakter di sekolah.

\section{DAFTAR RUJUKAN}

Almerico, G. M. (2014). Building Character Through Literacy with Children' S Literature. Higher Education Journal, $26,1-13$. Retrieved from https://files.eric.ed.gov/fulltext/ EJ1055322.pdf

Covaleskie, J. F. (2006). 2006 Ohio Valley Philosophy of Education Society. Philosophical Studies In Education, (1). Retrieved from https://files.eric.ed.gov/ fulltext/EJ1072412.pdf

Freeks, F. E. (2015). The Influence of role-players on the character- development and character-building of South African college students. South African Journal of Education, 35(3). Retrieved from https://files.eric.ed.gov//fulltext/EJ1134893.pdf

Jusita, M. L. (2006). Pengembangan Nilai-Nilai Karakter Dalam Aktivitas Belajar Menggunakan Media Pembelajaran

"Pecango". Jurnal Teori dan Praksis Pembelajaran IPS, 1(1), 2-6. http://dx.doi.org/10.17977/um022v1i12016p02h2

Kementerian Pendidikan Dan Kebudayaan. (2013). Konsep dan Pedoman Penguatan Pendidikan Karakter. Jakarta: Kementerian Pendidikan dan Kebudayaan.

Kementerian Pendidikan Nasional. (2010). Kerangka Acuan Pendidikan Karakter tahun Anggaran 2010. Jakarta: Kementerian Pendidikan Nasional.

Marini, A. (2017). Integration of Character Values in School Culture at Elementary. Journal of Art and Humanities, 6(5), 2132. http://dx.doi.org/10.18533/journal.v6i5.1171

Muslich, M. (2011). Pendidikan Karakter: Menjawab Tantangan Krisis Multidimensional. Jakarta: Bumi Aksara.

Narwanti, S. (2011). Pendidikan Karakter: Pengintegrasian 18 Nilai Pembentuk Karakter dalam Mata Pelajaran. Yogyakarta: Familia.

Rahim, A., Raisul, S., \& Abdoludin, I. (2016). Character Issues : Reality Character Problems and Solutions through Education in Indonesia. Journal of Education and Practice, 7(17), 158-165.

Samani, M. (2012). Konsep dan Model Pendidikan Karakter. Bandung: Rosdakarya.

Shangaraeva, L. F., \& Yarkhamova, A. A. (2016). The Formation of Students' Creative Independence at the English Language Classes. International Journal of Environmental \& Science Education, 11(6), 1267-1274. https://doi.org/10.12973/ijese.2016.397a

Simba, N. O., Agak, J. O., \& Kabuka, E. K. (2016). Impact of Discipline on Academic Performance of Pupils in Public Primary Schools in Muhoroni Sub-County, Kenya. Journal of Education and Practice, 7(6), 164-173.

Sulistiyo, H. (2014). Relevansi Nilai Religius Dalam Mencegah Perilaku Disfungsional Audit. Jurnal Ekonomi Manajemen dan Akuntansi, 21(36), 1-13. 
Sunarty, K., \& Dirawan, G. D. (2015). Development Parenting Model to Increase the Independence of Children. International Education Studies, 8(10), 107-113. http://dx.doi.org/10.5539/ies.v8n10p107

Thresia, F. (2015). Integrating Local Culture to Promote Character Education In Teaching Writing. Premise: Journal of English Education, 4(1). DOI: http://dx.doi.org/10.24127/pj.v4i1.276

Wantah, M. (2015). Pengembangan Disiplin dan Pembentukan Moral pada Anak Usia Dini. Jakarta: Depdiknas.

Wiyani, N. A. (2013). Konsep, Praktik, \& Strategi Membumikan Pendidikan Karakter di SD. Yogyakarta: Ar-Ruzz Media. 